\title{
KENYA GAME DEPARTMENT REPORT, 1950
}

An extract from the report of J. A. Hunter, Game Ranger, Makindu Area

For very many years the areas west of the railway line comprising Kibwezi, Makindu, Kiboko and Simba have been the mecca for numbers of the native poaching fraternity. A change exists. Now that game preservation has been strictly enforced, these skilled Wakamba hunters and experts in the use of bow and poisoned arrow have taken badly to existing conditions. Game animals ranging from elephant to dikdik in the past went through bad times in a grim endeavour to survive. Their drinking places during periods of excessive drought had their quota of poachers' hides, either hollowed out in mother earth or built on adjacent trees. Twang of bowstring had brought about in the minds of wild creatures a note inherited, conveying fear and alarm. Nothing on four legs was sparedfemales and young-easy food.

Motor trails have now given access to the unfrequented and lesser known places; since this was accomplished poaching has practically stopped to a pleasing degree.

In a lava belt up the Kiboko Stream, Game Ranger Bousfield and myself came on a veritable poachers' cave or "hotel", evidently a favoured place and doubtless used over scores of years. Here hall-marks of their calling remained, which included pieces of rhino and giraffe hide while horns and bones of at least half of the animals mentioned on the game schedules lay strewn around. Meat drying frames were stoutly built, while watergourds were shelved in the crannies of the time-aged walls. Poachers hunted in gangs and congregated at this particular place.

The last party was unlucky; I had an armed scout patrol hidden nearby. 'The result - a scrimmage, a capture, and the delinquents arrayed before the magistrate, Machakos. Instead of easy meat, hard labour was imposed. News of capture soon gets around amongst the tribe and these arcas to a major extent have been given a miss. In the poachers' favour, they were somewhat at a loss to understand why they were caught and imprisoned ; they had only followed their fathers' calling.

Motor tracks would appear invaluable and the answer to saving much of the game. That is not all--beasts in this area are returning to their old ways and drinking by daylight hours instead of by night. It is gratifying to observe that rhino and buffalo are considerably on the increase; the former may be seen meandering in the open grasslands during daytime. 
Elephants are frequently seen, but in the areas to which I refer their ivory is poor. Somehow it would appear that vegetation on lava belts is not ivory producing compared with the feeding eastwards on the Athi-Yatta areas.

Native bone collectors have been busy in the district; bleached game skeletons (grim reminders of the past) are carried and piled high for collection by lorry. I saw three such piles in a small area which represented the remains of several hundred game animals. The Makindu-Kiboko region has a unique showing of fringe-eared oryx, while lesser kudu are well represented. It is curious that waterbuck and lesser kudu mingle freely together. Felines are not plentiful, but jackal, bat-eared fox, and aard-vark are common. "Bush babies" are many amongst the trees fringing the Kiboko watercourse.

Two incidents seen may be worth recording:-

The first occasion-a member of the eagle family was seen to pounce down to earth when a moment later considerable movement was in progress. Venturing nearer by lorry $\mathbf{I}$ was surprised to see the eagle rise about 10 feet from the ground with something fairly big in its talons and drop its load. While I watched this was repeated five times; getting closer, I noticed the catch was a piglet. Its weight I later guessed at $7 \mathrm{lb}$. Thinking I could manage still nearer, I crawled within 12 feet, when the eagle spotted me, and in alarm left the bait. 'The piglct was still alive but both eyes had been pecked out. I killed and left it for the attacker, which remained perched on a tree a hundred yards distant.

The other instance happened in the same area and, if $I$ am not mistaken, the same eagle was the assailant, from the marking and description of this bird, an immature martial eagle.

One of my scouts first saw the incident, an eagle having a rare old tussle with what at first glance appeared to be a snake. The similarity - the eagle was in battle with a bat-eared fox which lay on its back with its fuzzy tail erect and flailing snake-like fashion.

On this occasion the fight was not going too well for the eagle. The scouts and myself were most interested spectators : slowly I sidled the lorry to within 12 yards of the scene. The fox was phucky and bit savagely at the upper parts of the eagle's legs. Thrice did we hear the notes of pain from the eagle- "queeoh, queeoh". This highly delighted the scouts; their peals of laughter caught the bird's ear, it became alarmed, and quit the fight. The fox, though in a bad and bedraggled state, managed to get up and scuttered into a nearby burrow. 